\title{
KALIMAT MAJEMUK BAHASA MINANGKABAU DALAM KABA
}

\section{Efri Yades}

\begin{abstract}
The paper examines the use of Minangkabau language compound sentences in kaba as literatur creation of Minangkabaunesse. The research was conducted to identify the kind of compound sentences used in kaba and to explain the structure. Based on the research, it is found compound sentences which are used in kaba are three kinds namely: cootdinative compound sentences, subordinative compound sentences, and combined compound sentences. Beside that, based on the amount of clauses it found that compound sentences consist of 3 clauses, 4 clauses, 5 clauses, 6 clauses, 7 clauses, 8 clauses, and 9 clauses. On the other hand, compound sentenses in kaba use conjungtion namely: jo 'and', sarato 'and', namum 'but', lalu 'than', sasudah 'after', kok 'if', and dek 'because. Minangkabau language compound sentences in kaba use structure namely: P-S,P-P-K; Konj-P-PelKonj-Pel-Ket,S-S-P,S-P,S-P; P-S,P-S,P-S,Ket-S,Ket-S; P-S,P-S,P-S,KetS,Ket-S; Ket-P,P-O,P-Pel,P-Pel-Ket; P-O,P-S,P-Ket,S-P; Ket-P-S,P-Ket, P-Ket; P-Ket,P-S-Ket,Ket-P-Ket,P-P,P-Ket,P-Ket,S-P-Pel,Ket-Ket,S-P.
\end{abstract}

Keyword: Minangkabau language, compound sentenses, kaba

\section{PENDAHULUAN}

Bahasa Minangkabau merupakan salah satu bahasa daerah yang ada di negara RI yang mempunyai kedudukan dan fungsi yang tinggi bagi masyarakat.pendukung budaya Minangkabau yang digunakan untuk berkomunikasi antar masyarakat. Bahasa Minangkabau juga sebagai bahasa pertama bagi sebahagian masyarakat Minangkabau untuk menyampaikan pikiran dan perasaan mereka baik dalam kehidupan sehari-hari maupun dalam berkarya sastra. Berkarya sastra itu salah satunya adalah bakaba yaitu bercerita, sedangkan hasil dari bakaba itu adalah kaba. Kaba merupakan salah satu jenis karya sastra tradisional lisan Minangkabau dan sekarang sudah 
beberapa kaba ditulis dan diterbitkan (Junus, 1984 : 17 dan Navis, 1986 : 220).

Bahasa Minangkabau yang digunakan dalam kaba berbeda dengan yang digunakan dalam kehidupan sehari-hari. Perbedaan itu terletak pada pilihan kata, gaya bahasa, dan jenis kalimat yang digunakan. Pilihan kata, gaya bahasa, dan kalimat yang digunakan dalam kehidupan sehari-hari cendrung umum, sedangkan yang digunakan dalam kaba bersifat unik. Hal ini sesuai dengan penjelasan Navis (1986 : 245) yaitu bahasa Minangkabau dalam kaba menggunakan kata-kata yang utuh, kalimat luas, dan gaya bahasa prosa liris, serta ungkapan plastis. Oleh karena itu, penulis tertarik untuk membahas lebih lanjut tentang penggunaan bahasa Minangkabau dalam kaba. Pada kesempatan ini akan dibahas tentang penggunaan bahasa Minangkabau dalam kaba dari segi penggunaan kalimat luas atau kalimat majemuk. Berdasarkan uraian di atas, dirumuskan masalah yang akan dibahas yaitu bagaimana struktur kalimat majemuk yang digunakan dalam $k a b a$, sedangkan tujuan penulisan untuk menjelaskan struktur kalimat majemuk yang digunakan dalam kaba.

Kalimat merupakan satuan bahasa terkecil yang mengungkapkan pikiran yang utuh yang berwujud lisan maupun tulisan. Dalam wujud lisan, kalimat diucapkan dengan suara naik turun, keras, lembut, disela jeda, dan diakhiri dengan intonasi akhir, sedangkan dalam wujud tulisan kalimat dimulai dengan huruf kapital dan diakhiri dengan tanda baca (Alwi dkk, 2003 : 311 ; Tarigan, 1983 ; Ramlan, 1996 : 27). Tiap kata atau frase dalam kalimat mempunyai fungsi yang mengaitkannya dengan kata atau frase lain yang ada dalam kalimat tersebut. Fungsi ini bersifat sintaksis yaitu berhubungan dengan urutan kata atau frase dalam kalimat yang terdiri atas Subjek (S), Predikat (P), Objek (O), Pelengkap (Pel), dan Keterangan (Ket). Namun, kelima unsur tersebut tidak selalu bersama-sama ada dalam satu kalimat, tetapi unsur Subjek (S) dan Predikat (P) harus ada (Putrayasa, 2009 : 64).

Berdasarkan jumlah klausa, kalimat dapat dibedakan atas kalimat sederhana dan kalimat luas (Ramlan, 1996 : 49). Selanjutnya, Ramlan menjelaskan bahwa kalimat sederhana adalah kalimat yang terdiri atas satu klausa, sedangkan kalimat luas merupakan kalimat yang terdiri atas dua atau lebih klausa. Selanjutnya, (Alwi dkk, 200 : 336) menyatakan bahwa kalimat berdasarkan jumlah klausa terdiri atas kalimat tunggal dan kalimat majemuk. Jadi, kalimat sederhana atau tunggal merupakan kalimat yang terdiri atas satu klausa, sedangkan kalimat luas atau majemuk yaitu kalimat 
yang mempunyai lebih dari satu klausa. Dalam artikel ini, selanjutnya digunakan istilah kalimat majemuk.

Kalimat majemuk terdiri atas tiga jenis, yaitu : kalimat majemuk setara, kalimat majemuk bertingkat, dan kalimat majemuk campuran (Arifin dan Junaiyah, 2008 : 62-69). Kalimat majemuk setara adalah kalimat majemuk yang terdiri atas dua klausa atau lebih yang digabungkan dengan kata penghubung yang menunjukkan kesetaraan (Arifin dan Junaiyah, 2008 : 62 ; Putrayasa, 2009 : 55). Kalimat majemuk bertingkat merupakan kalimat yang terdiri atas unsur induk kalimat dan unsur anak kalimat (Arifin dan Junaiyah, 2008 : 62). Induk kalimat merupakan inti gagasan, sedangkan anak kalimat adalah gagasan yang dihubungkan dengan gagasan induk kalimat. Akan tetapi, kalimat majemuk campuran adalah kalimat majemuk yang terdiri atas kalimat majemuk setara dan kalimat majemuk bertingkat (Arifin dan Junaiyah, $2008: 68$ ).

Dalam kerangka pemecahan masalah, diperlukan langkah-langkah kerja yang nyata. Dalam hal ini dilakukan tiga tahap kerja, yaitu : tahap penyediaan data, tahap analisis data, dan tahap penyajian hasil analisis. Ketiga tahap tersebut dilakukan dengan teliti agar hasil yang diinginkan tercapai.

Pada tahap penyediaan data digunakan metode simak dengan teknik sadap sebagai teknik dasar, dan teknik catat sebagai teknik lanjutan (Sudaryanto, 1993 : 133). Data diambil dari kaba klasik Minangkabau yang sudah dituliskan dan diterbitkan oleh Kristal Multimedia. Tahap analisis data digunakan metode padan dan metode agih. Metode padan yang digunakan adalah metode padan referensial dan translasional. Selanjutnya, juga digunakan metode agih dengan teknik dasar bagi unsur langsung dan teknik lanjutan yaitu teknik lesap, teknik ganti, teknik balik dan teknik ubah wujud. Terakhir, pada tahap penyajian hasil analisis digunakan metode informal.

\section{KALIMAT MAJEMUK DALAM KABA}

Dalam kaba terdapat penggunaan kalimat majemuk bahasa Minangkabau yang bervariasi jenisnya maupun strukturnya. Berikutnya ini adalah beberapa contoh kalimat majemuk bahasa Minangkabau yang digunakan dalam kaba beserta pembahasannya. 
(1) $\frac{\text { Alah duduak }}{\mathrm{P}} \frac{\text { Sabai Nan Aluih }}{\mathrm{S}} \frac{\text { duduak }}{\mathrm{P}} \frac{\text { basimpuah }}{\mathrm{P}} \frac{\text { di muko mandeh. }}{\mathrm{K}}$.

'Sabai Nan Aluih sudah duduk, duduk bersimpuh di depan ibu.'

Kalimat majemuk pada contoh (1) termasuk kalimat majemuk setara yang terdiri atas dua klausa yaitu: klausa (1) alah duduak Sabai Nan Aluih 'Sabai Nan Aluih sudah duduk' dan klausa (2) duduak basimpuah di muko mandeh 'duduk bersimpuh di depan ibu'.Kedua klausa tersebut tidak dihubungkan oleh konjungtor, tetapi hanya dibatasi koma. Klausa yang pertama berstruktur P-S, sedangkan klausa yang kedua berstruktur P-P-K. Klausa yang berstruktur P-S ini termasuk klausa inversi yaitu fungsi sintaksis P mendahului S, sedangkan klausa yang kedua merupakan klausa tak lengkap karena tidak memiliki fungsi sintaksis S. Jadi,Contoh (1) adalah kalimat majemuk setara berstruktur P-S,P-P-K.

(2) Kok tumbuah alek jo jamu, di dalam korong kampuang urang, Konj P Pel Konj Pel Ket panggilan usah anak tulak, adatnyo diisi limbagonyo dituang.

$\begin{array}{llllllll}\mathrm{S} & \mathrm{S} & \mathrm{P} & \mathrm{S} & \mathrm{P} & \mathrm{S} & \mathrm{P}\end{array}$

' Jika ada pesta di kampung orang, kamu jangan menolak undangannya, kamu harus mengikuti aturan yang ada.'

Kalimat majemuk yang terdapat pada contoh (2) adalah kalimat majemuk campuran antara kalimat majemuk bertingkat dengan kalimat majemuk setara. Kalimat majemuk ini di awali klausa subordinatif yang ditandai adanya konjungtor kok 'karena' di awal klausa lalu diikuti klausa induk. Kalimat majemuk ini terdiri atas empat klausa yaitu: klausa (1) kok tumbuah alek jo jamu 'jika ada pesta', klausa (2) di dalam korong kampuang urang 'di kampung orang', klausa (3) panggilan usah anak tulak 'jangan kamu tolak undangannya', klausa (4) adatnyo diisi 'adatnya diisi', dan klausa (5) limbagonya dituang 'lembaganya dituang'. Klausa pertama dihubungkan oleh konjungtor kok 'jika' dengan klausa kedua, sedangkan klausa kedua, ketiga, dan keempat tidak ada konjungtor yang menghubungkan, tetapi hanya ditandai dengan koma.

Klausa (1) berstruktur Konj-P-Pel-Konj-Pel, klausa (2) berstruktur Ket, klausa (3) berstruktur S-S-P, klausa (4) berstruktur S-P, dan klausa (5) 
berstruktur S-P. Klausa (1) dan (2) merupakan klausa tak lengkap karena klausa ini tidak memiliki fungsi sintaksis S, sedangkan klausa (3), (4), dan (5) adalah klausa lengkap karena memiliki fungsi sintaksis S-P. Jadi, Kalimat majemuk ini berstruktur Konj-P-Pel-Konj-Pel-Ket,S-S-P,S-P,S-P.

(3) Limbak nan dari pado itu, Si Kutak marauik alang-alamg, baraja maukia Ket $\mathrm{P}$ $\mathrm{P} \quad \mathrm{P}$ samo panjang, baraja mangati samo barek, kok taraju nan bapaliang.

Pel $\mathrm{P} \quad \mathrm{P}$ Pel $\mathrm{S}$

'Selain daripada itu, Si Kutak meraut layang-layang, belajar memotong sama panjang, belajar menimbang sama berat, kalau teraju yang berpaling.'

Kalimat (3) merupakan kalimat majemuk campuran yang terdiri atas empat klausa yaitu: klausa (1) limbak nandari pado itu si Kutak marauik alang-alang 'selain daripada itu si Kutak meraut layang-layang', klausa (2) baraja maukia samo panjang 'belajar memotong sama panjang', klausa (3) baraja mangati samo barek 'belajar menimbang sama berat', dan klausa (4) kok taraju nan bapaliang 'kalau teraju yang berpaling'. Klausa pertama, kedua, dan ketiga tidak ada konjungtor yang menghubungkannya, tetapi hanya dibatasi tanda koma yang berarti ketiga klausa tersebut setara. Namun, klausa ketiga dihubungkan dengan konjungtor kok 'kalau' dengan klausa keempat.

Jika dilihat struktur setiap klausanya, klausa (1) berstruktur Ket-S-P-O, klausa (2) berstruktur P-P-Pel, klausa (3) berstruktur P-P-Pel, dan klausa (4) berstruktur Konj-S. Klausa lengkap terdapat pada klausa (1), sedangkan klausa tidak lengkap terdapat pada klausa (2), (3), dan (4). Jadi, kalimat majemuk ini berstruktur Ket-S-P-O, P-P-Pel,P-P-Pel Konj-S.

(4) Sajak maliek rupo si Sabai, tabayang-bayang di ruang mato, dibaok $\begin{array}{llllll}\text { Konj } & \mathrm{P} & \mathrm{O} & \mathrm{P} & \text { Ket } & \mathrm{P}\end{array}$ duduak tak sanang, dibaok tagak kaluah kasah, bak dilembai api nyalo, $\begin{array}{llllll}\mathrm{P} & \mathrm{P} & \mathrm{P} & \mathrm{P} & \mathrm{P} & \end{array}$ siang manjadi angan-angan, malam manjadi turo-turo, sungguahpun
$\mathrm{S} \quad \mathrm{P}$
Pel
$\mathrm{S}$
$\mathrm{P}$
Pel

umuanyo alah lanjuik, parampuan tatap duo tigo.

$\mathrm{S} \quad \mathrm{P} \quad \mathrm{S} \quad \mathrm{P}$

' Sejak raja itu melihat wajah si Sabai, terbayang-bayang di ruang mata, dibawa duduk tidak senang, dibawa tegak keluh kesah, seperti dilembai api 
nyala, siang menjadi angan-angan, malam menjadi pikiran, sungguhpun umurnya sudah lanjut, istrinya tetap banyak.'

Kalimat (4) di atas adalah kalimat majemuk yang terdiri atas sembilan klausa yaitu: klausa (1) sajak maliek rupo si Sabai 'sejal melihat wajah si Sabai', klausa (2) tabayang-bayang di ruang mato 'terbayang-bayang di ruang mata', klausa (3) dibaok duduak tak sanang 'dibawa duduk tidak senang', klausa (4) dibaok tagak kaluah kasah 'dibawa tegak keluh kesah', klausa (5) bak dilembai api nyalo 'seperti dilembai api nyalo', klausa (6) siang manjadi angan-angan 'siang menjadi angan-angan', klausa (7) malam manjadi pikiran 'malam menjadi pikiran', klausa (8) sungguahpun umuanyo alah lanjuik 'sungguhpun umurnya sudah lanjut', dan klausa (9) parampuan tatap duo tigo 'perempuan tetap dua tiga'. Klausa pertama dihubungkan oleh konjungtor sajak 'sejak' dengan klausa berikutnya, klausa kelima dihubungkan oleh konjungsi bak 'seperti' dengan klausa keenam, dan klausa kedelapan dihubungkan oleh konjungtor sungguahpun 'sungguhpun' dengan klausa kesembilan pada kalimat tersebut.

Struktur tiap-tiap klausa kalimat majemuk ini adalah klausa (1) berstruktur Konj-P-O, klausa (2) berstruktur P-Ket, klausa (3) berstruktur P-P-P, klausa (4) berstruktur P-P-P, klausa (5) berstruktur Konj-P-Pel, klausa (6) berstruktur S-P-Pel, klausa (7) berstruktur S-P-Pel, klausa (8) berstruktur Konj-S-P, dan klausa (9) berstruktur S-P. Kalimat majemuk ini termasuk kalimat majemuk campuran berstruktur Konj-P-O,P-Ket,P-P-P,P-P-P,KonjP-Pel,S-P-Pel,S-P-Pel,Konj-S-P,S-P.

(5) Duduaklah kaduo rajo nantun, bahadok bamuko-muko, sarato pangiriang $\mathrm{P} \quad \mathrm{S}$ $\mathrm{P} \quad \mathrm{P}$ $\mathrm{S}$ baliak batimba. $\mathrm{P}$

' Kedua raja itu duduk berhadap-hadapan dan pengiring duduk timbalbalik.'

Kalimat majemuk (5) di atas termasuk kalimat majemuk setara yang dihubungkan oleh konjungtor sarato 'serta' antarklausa kedua dan ketiga, sedangkan antara klausa pertama dengan klausa kedua tidak ada konjungtur, tetapi dibatasi dengan koma. Kalimat majemuk ini terdiri atas tiga klausa yaitu: klausa (1) duduaklah kaduo rajo nantun 'duduklah kedua raja itu', klausa (2) bahadok bamuko-muko 'berhadap-hadapan', dan 
klausa (3) sarato pangiriang baliak-batimba 'pengiring timbal-balik'. Klausa (1) berstruktur P-S dan termasuk klausa inversi karena fungsi sintaksis S didahului fungsi P dalam klausa tersebut. Klausa (2) berstruktur P-P dan termasuk klausa tidak lengkap karena tidak mempunyai fungsi sintaksis $\mathrm{S}$. Klausa (3) berstruktur Konj-S-P dan termasuk klausa lengkap. Jadi, Kalimat majemuk ini mempunyai struktur P-S,P-P,Konj-S-P.

(6) Lah tagak pulo Rajo Babandiang, tagak sarato jo pangiriang, pangiriang $\begin{array}{llll}\mathrm{P} & \mathrm{S} & \mathrm{P} & \text { Ket }\end{array}$ $\mathrm{S}$

baliak batimba, mancari sasaran surang-surang.

Ket $\mathrm{P} \quad \mathrm{O}$

' Rajo Babandiang sudah berdiri dengan pengiring timbal balik, mereka mencari sasaran masing-masing.'

Kalimat (6) merupakan kalimat majemuk setara yang memiliki empat klausa yaitu: klausa (1) lah tagak pulo Rajo Babandiang 'Rajo Babandiang sudah berdiri', klausa (2) tagak sarato jo pangiriang 'berdiri dengan pengiring', klausa (3) pangiriang baliak batimba 'pengiring timbal balik', dan klausa (4) mancari sasaran surang-surang 'mencari sasaran masing-masing'. Pada kalimat majemuk tersebut tidak ada konjungtor yang menghubungkan antarklausa tersebut. Antarklausa hanya dibatasi oleh koma dan kalimat majemuk setara ini berstruktur P-S,P-Ket,S-Ket,P-O. Setiap klausa mempunyai struktur sebagai berikut: klausa (1) berstruktur $P=S$, klausa (2) berstruktur $\mathrm{P}=$ Ket, klausa (3) berstruktur S-Ket, dan klausa (4) berstruktur P-O. Selanjutnya, klausa (1) termasuk klausa lengkap dan klausa inversi karena klausa tersebut memiliki fungsi sintaksis $\mathrm{S}$ dan fungsi sintaksis $\mathrm{P}$ mendahului fungsi sintaksis S, klausa (2) dan (4) termasuk klausa tidak lengkap karena tidak memiliki fungsi sintaksis S, serta klausa (3) termasuk klausa lengkap.

(7) Sadanglah Rajo Nan Panjang, mahariak mahantam tanah, bakato putuih $\underline{\text { inyo di sanan. }}$.

$$
\mathrm{S} \quad \mathrm{P} \quad \mathrm{P} \quad \mathrm{O} \quad \mathrm{P} \text { Pel }
$$

S Ket

' Ketika Rajo Nan Panjang menghardik menghantam tanah, dia berkata putus di situ.'

Kalimat (7) ini adalah kalimat majemuk campuran dan terdiri atas tiga klausa yaitu: klausa (1) sadanglah Rajo Nan Panjang 'ketika Rajo Nan 
Panjang', klausa (2) mahariak mahantam tanah 'menghardik menghantam tanah', dan klausa (3) bakato putuih inyo di sanan 'dia berkata putus di situ'. Klausa pertama dengan klausa berikutnya dihubungkan oleh konjungtor sadanglah 'ketika'. Kalimat majemuk ini berstruktur Konj-S,P-P-O,P-Pel-SKet. Setiap klausa berstruktur sebagai berikut: klausa (1) berstruktur Konj-S, klausa (2) berstruktur P-P-O, dan klausa (3) berstruktur P-Pel-S-Ket.

(8) Malangkah Rajo Nan Panjang, direnjeng kaki nan suok, dikiraikan $\begin{array}{lllll}\mathrm{P} & \mathrm{S} & \mathrm{P} & \mathrm{Pel} & \mathrm{P}\end{array}$ tangan nan kida, digelekkan pinggang ka dalam, ikua mato maintai $\begin{array}{llllll}\text { Pel } & P & \text { Pel } & \text { Ket } & \text { S } & P\end{array}$ lawan.

$\mathrm{O}$

' Rajo Nan Panjang melangkah, diangkat kaki yang kanan, dikibaskan tangan yang kiri, dikisarkan pinggang ke dalam, ekor mata mengintai lawan.'

Kalimat pada data (8) adalah kalimat majemuk setara yang terdiri atas lima klausa yaitu: klausa (1) malangkah Rajo Nan Panjang 'Rajo nan Panjang melangkah', klausa (2) direnjeng kaki nan suok 'diangkat kaki yang kanan', klausa (3) dikiraikan tangan nan kida 'dikibaskan tangan yang kiri', klausa (4) digelekkan pinggang ka dalam 'dikisarkan pinggang ke dalam', dan klausa (5) ikua mato maintai lawan 'ekor mata mengintai lawan'. Antarklausa pada kalimat itu tidak menggunakan konjungtor, tetapi menggunakan tanda koma untuk memisahkan setiap klausa. Kehadiran konjungtor di sini tidak wajib karena tanpa kehadiran konjungtor kalimat tetap berterima. Jika dilihat struktur yang digunakan, kalimat majemuk ini berstruktur P-S,PPel,P-Pel,P-Pel-Ket,S-P-O. Selanjutmya, setiap klausa berstruktur sebagai berikut: klausa (1) berstruktur P-S termasuk klausa inversi, klausa (2) berstrulktur P-Pel, klausa (3) berstruktur P=Pel, klausa (4) berstrutur P-PelKet, dan klausa (5) berstruktur S-P-O.

(9) Lorong kapado Palimo Padamg Tarok baduo dangan si Bujang Salamat, $\mathrm{S}$

dek mandanga latusan badia, Rajo Babandiang lah rabah pulo, sadang $\begin{array}{llll}\mathrm{P} & \mathrm{O} & \mathrm{S} & \mathrm{P}\end{array}$

marunguih maharang panjang, tabiklah takuik ngari ganta, takuik $\underline{\mathrm{ka}}$

$\begin{array}{lllll}\mathrm{P} & \mathrm{P} & \mathrm{P} & \mathrm{Pel} & \mathrm{P}\end{array}$

umpan badia pulo, lari dareh maso nantun.

Ket $\mathrm{P}$ Ket 
' Kembali kepada cerita Palimo Padang Tarok dan si Bujang Salamat, karena mereka mendengar letusan bedil, Rajo Babandiang sudah rebah pula dan sedang meringis mengherang panjang, terbitlah takut mereka untuk menjadi umpan bedil sehingga mereka lari ketika itu.'

Kalimat pada data (9) di atas adalah kalimat majemuk campuran yaitu gabungan dari kalimat majemuk bertingkat dengan kalimat majemuk setara. Kalimat majemuk bertingkat ditandai dengan adanya konjungtor dek 'karena' yang menghubungkan klausa pertama dengan klausa berikutnya. Namun, kalimat majemuk setara tidak menggunakan konjungtor. Kalimat majemuk ini terdiri atas tujuh klausa yaitu: klausa (1) lorong kapado Palimo Padang Tarok baduo dangan si Bujang Salamat 'Kembali kepada cerita Palimo Padang Tarok dan si Bujang Salamat', klausa (2) dek mandanga latusan badia 'karena mendengar letusan bedil', klausa (3) Rajo babandiang lah rabah pulo 'Rajo Babandiang telah rebah pula', klausa (4) sadang marunguih maharang panjang 'sedang meringis mengherang panjang, klausa (5) tabiklah takuik ngari ganto 'terbitlah takut mereka'klausa (6) takuik kaumpan badia pulo 'takut menjadi umpan bedil', dan klausa (7) lari dareh maso nantun ' lari cepat masa itu'.

Jika dilihat struktur setiap klausa, klausa (1) berstruktur Ket-S, klausa (2) berstruktur Konj-P-O, klausa (3) berstruktur S-P, klausa (4) berstruktur P-P, klausa (5) berstruktur P-Pel, klausa (6) berstruktur P-Ket, dan klausa (7) berstruktur P-Ket. Jadi, kalimat majemuk ini berstruktur Ket-S,konj-PO,S-P,P-P,P-Pel,P-Ket,P-Ket.

(10)Sadang inyo tarangah-angah, disapu juo paluah jo deta, maningadah $\mathrm{ka}$ $\begin{array}{llllll}\text { Konj } & \mathrm{S} & \mathrm{P} & \mathrm{P} & \text { Pel Ket } \mathrm{P}\end{array}$ ateh rumah, tadanga bunyi urang batanun, sadamg maluntua-luntuakan Ket $\mathrm{P} \quad \mathrm{S} \quad \mathrm{P}$ tarok, lalu mahimbau anak gubalo. $\mathrm{O} \quad \mathrm{P} \quad \mathrm{S}$

' Ketika dia terengah-engah, keringat dilap dengan deta, dia meningadah ke atas rumah, terdengar olehnya bunyi orang bertenun yang sedang menggerak-gerakan alat tenun, lalu anak gembala memanggil orang rumah.'

Kalimat pada data (10) termasuk kalimat majemuk campuran yang terdiri atas enam klausa yaitu: klausa (1) sadang inyo tarangah-angah ' ketika dia terengah-engah', klausa (2) disapu juo paluah jo deta 'keringat dilap juga dengandeta', klausa (3) maningadahlah ka ateh rumah'dia meningadah ke atas 
rumah', klausa (4) tadanga urang batanun 'terdengar olehnya bunyi orang bertenun', klausa (5) sadang maluntua-luntuakan tarok 'sedang menggerakgerakan alat tenun' dan klausa (6) lalu maimbau anak gubalo 'lalu anak gembala memanggil orang rumah'. Klausa pertama dihubungkan dengan klausa kedua menggunakan konjungtor sadang 'ketika'. Klausa kedua, ketiga, keempat, dan kelima tidak menggunakan konjungtor, tetapi menggunakan tanda koma. Klausa kelima dengan keenam dihubungkan dengan konjungtor lalu 'lalu'.

Setiap klausa mempunyai struktur sebagai berikut: klausa (1) berstruktur Konj-S-P, klausa (2) berstruktur P-Pel-Ket, klausa (3) berstruktur P-Ket, klausa (4) berstruktur P-S, klausa (5) berstruktur P-O, dan klausa (6) berstruktur P-S. Jadi, kalimat majemuk ini berstruktur Konj-S-P,P-PelKet,P-Ket,P-S,P-O,P-S.

(11)Kununlah Sadun Saribai, sungguahpun ramuak dalam hati, dibujuak juo $\begin{array}{lllll}\text { Ket } & \mathrm{S} & \mathrm{P} & \text { Ket } & \mathrm{P}\end{array}$ anak kanduang. $\mathrm{S}$

' Kononlah, sungguhpun Sadun Saribai dalam hatinya remuk, anaknya tetap dibujuk .'

Kalimat (11) di atas merupakan kalimat majemuk bertingkat yang antarklausanya dihubungkan oleh konjungtor sungguahpun 'sungguhpun' . Kalimat majemuk ini terdiri atas tiga klausa yaitu: klausa (1) kununlah Sadun Saribai 'kononlah Sadun Saribai', klausa (2) sungguahpun ramuak dalam hati 'sungguhpun dalam hatinya remuk', dan klausa (3) dibujuak juo anak kanduang 'anaknya tetap dibujuk'. Klausa yang kedua adalah klausa subordinatif sedangkan klausa ketiga merupakan klausa induk. Kalimat majemuk ini berstruktur Ket-S,Konj-P-Ket,P-S. Struktur setiap klausa adalah klausa (1) berstruktur Ket-S, klausa (2) berstruktur Konj-P-Ket, dan klausa (3) berstruktur P-S.

(12) Mandanga kato nan bak kian, batambah sakik hati si Sabai, luko diracik$\mathrm{P} \quad \mathrm{O}$ $\mathrm{P} \quad \mathrm{P}$ $\mathrm{S}$ $\mathrm{S}$ $\mathrm{P}$

kan asam pulo. Pel

'Mendengar kata seperti itu, hati si Sabai bertambah sakit, luka diberi asam pula.' 
Kalimat (12) merupakan kalimat majemuk campuran terdiri atas tiga klausa yaitu: klausa (1) mandanga kato nan bak kian 'mendengar kata sepert itu', klausa (2) batambah sakik hati si Sabai'hati si Sabai bertambah sakit', dan klausa (3) luko diracik asam pulo 'luka diberi pula asam'. Antarklausa dibatasi oleh koma atau tanpa menggunakan konjungtor. Klausa pertama merupakan klausa subordinatif sebab, tetapi konjungtornya dilesapkan. Kalimat majemuk ini berstruktur P-O,P-P-S,S-P-Pel. Struktur tiap-tiap klausa adalah sebagai berikut: klausa (1) berstruktur P-O, klausa (2) berstruktur P-P-S, dan klausa (3) berstruktur S-P-Pel.

(13) Birawari Rajo Nan Panjang, turun bagageh ateh kudo, dipatuik badan $\begin{array}{lllllll}\text { Ket } & \mathrm{S} & \mathrm{P} & \mathrm{P} & \text { Ket } & \mathrm{P} & \mathrm{S}\end{array}$ sambia malangkah, lalu manyapo inyo di sanan. $\mathrm{P} \quad \mathrm{P} \quad \mathrm{S}$ Ket

' Pada suatu hari Rajo Nan Panjang turun dari kuda dan bergaya sambil melangkah lalu dia menyapa di situ.'

Kalimat (13) adalah kalimat majemuk campuran yang terdiri atas lima klausa yaitu: klausa (1) birauwari Rajo Nan Panjang 'Pada suatu hari Rajo Nan Panjang', klausa (2) turun bagageh ateh kudo 'turun bergegas dari kuda', klausa (3) dipatuik badan ' dipatut diri', klausa (4) sambia malangkah 'sambil melangkah', dan klausa (5) lalu manyapo inyo di sanan 'lalu dia menyapa di situ'. Klausa pertama, kedua, dan ketiga tidak ada konjungtor yang digunakan untuk menghubungkannya, sedangkan klausa keempat dengan kelima dihubungkan oleh konjungtor sambia 'sambil'. Klausa kelima dihubungkan oleh konjungtor lalu 'lalu' dengan klausa keenam. Struktur kalimat majemuk ini adalah Ket-S,P-P-Ket,P-S-Konj-P,Konj-P,P-S-Ket. Setiap klausa mempunyai struktur seperti berikut ini, klausa (1) berstruktur Ket-S, klausa (2) berstruktur P-P-Ket, klausa (3) berstruktur P-S, klausa (4) berstruktur Konj-P, dan klausa (5) berstuktur P-S-Ket.

(14) Mandanga kato nan bak kian, bakato Rajo nan Panjang, bakato jo gadang $\begin{array}{llllll}\mathrm{P} & \mathrm{O} & \mathrm{P} & \mathrm{S} & \mathrm{P} & \text { Ket }\end{array}$ hati, urang harok nan buliah.

$\mathrm{S} P$

'Mendengar kata seperti itu, Rajo nan Panjang berkata dengan senang hati orang berharap yang baik .' 
Kalimat (14) di atas adalah kalimat majemuk campuran yang terdiri atas empat klausa yaitu: klausa mandanga kato nan bak kian 'mendengar kata seperti itu', klausa (2) bakato Rajo nan Panjang 'Rajo nan Panjang berkata', klausa (3) bakato jo gadang hati 'berkata dengan hati', dan klausa (4) urang harok nan buliah 'orang berharap yang baik". Dalam kalimat majemuk ini tidak terdapat penggunaan konjungtor setara maupun konjungtor subordinatif. Konjungtor subordinatif yang dilesapkan pada kalimat majemuk tersebut adalah konjungtor sebab dek 'karena'yang terletak di awal kalimat yaitu pada klausa subordinatif Dek mandanga kato nan bak kian 'Karena mendengar kata seperti itu'. Struktur setiap klausa adalah seperti berikut ini, klausa (1) berstruktur P-O, klausa (2) berstruktur P-S, klausa (3) berstruktur P-Ket, dan klausa (4) berstruktur S-P. Jadi, struktur kalimat majemuk ini adalah P-O,P-S,P-Ket,S-P.

(15) Kununlah Rajo Nan Panjang, mahariak mahantam tanah, $\underline{\text { bakato sambia }}$

Ket $\mathrm{S} \quad \mathrm{P} \quad \mathrm{P} \quad \mathrm{O} \quad \mathrm{P}$

mandareh, kapado si upiak Sabai Nan Aluih.

$\mathrm{P} \quad$ Ket

' Kononlah Rajo Nan Panjang menghardik menghantam tanah dan berkata Sambil memaksakan kehendak kepada si Upiak Sabai Nan Aluih.'

Kalimat pada contoh (15) di atas termasuk kalimat majemuk campuran dan terdapat penggunaan konjungtor subordinatif waktu sambia 'sambil', tetapi tidak ada penggunaan konjuntor setara. Kalimat majemuk ini terdiri atas lima klausa yaitu: klausa (1) kununlah Rajo Nan Panjang'kononlah Rajo Nan Panjang', klausa (2) mahariak mahantam tanah 'menghardik menghantam tanah', klausa (3) bakato 'berkata', klausa (4) sambia mandareh 'sambil memaksakan kehendak', dan klausa (5) kapado si upik Sabai Nan Aluih 'kepada si upik Sabai Nan Aluih'. Kalimat majemuk campuran ini berstruktur Ket-S,P-P-O,P,Konj-P,Ket. Setiap klausa berstruktur seperti berikut ini, klausa (1) berstruktur Ket-S, klausa (2) berstruktur P-P-O, klausa (3) berstruktur P, klausa (4) berstruktur Konj-P, dan klausa (5) berstruktur Ket.

(16) Alun pueh inyo maratok, direnjeng tagak kutiko nantun, dihapuih malah $\begin{array}{llll}\mathrm{P} & \mathrm{S} & \mathrm{P} & \mathrm{P} \\ \mathrm{Pel}\end{array}$ ayia mato, dituruik Sabai Nan Aluih, sambia malangkah mancareceh. $\begin{array}{lllll}S & P & S & \text { Konj } & P\end{array}$

' Dia belum puas menangis lalu berdiri ketika itu dan menghapus air mata- 
nya lalu ditemui Sabai Nan Aluih sambil melangkah dia merepet-repet.'

Kalimat pada contoh data (16) termasuk kalimat majemuk campuran yang terdiri atas lima klausa. Klausa-klausa tersebut adalah klausa (1) alun pueh inyo maratok'dia belum puas menangis', klausa (2) direnjeng tagak kutiko nantun 'berdiri ketika itu' klausa (3) dihapuih malah aia mato 'dihapuslah air mata' klausa (4) dituruik Sabai Nan Aluih 'ditemui Sabai Nan Aluih', dan klausa (5) sambia malangkah mancareceh 'sambil melangkah merepet-repet'. Antara klausa (1) dengan klausa (2), (3), dan (4) tidak ada konjungtor, sedangkan antara klausa (4) dengan klausa (5) terdapat konjungtor subordinatif yaitu konjungtor sambia 'sambil'.

Struktur tiap-tiap klausa adalah seperti berikut ini, struktur klausa (1) P-S-P, klausa (2) P-Pel-Ket, klausa (3) P-S, klausa (4) P-S, dan klausa (5) Konj-P-P. Klausa inversi terdapat pada klausa (1), (3), dan (4) karena pada ketiga klausa tersebut fungsi sintaksis $S$ terletak setelah fungsi sintaksis P. Klausa (2) dan klausa (5) termasuk klausa tidak lengkap karena kedua klausa itu tidak mempunyai fungsi sintaksis S. Jadi, struktur kalimat majemuk campuran tersebut adalah P-S-P, P-Pel-Ket, P-S, P-S, Konj-P-P.

(17) Hari baransua rambang sanjo, sanan takajuik lareh nantun, takana bana

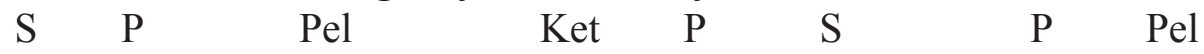

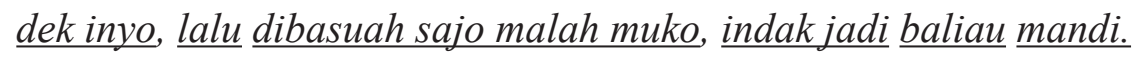
$\begin{array}{lllllll}\text { Ket Konj } & p & \text { Pel } & P & \text { S } & P\end{array}$

'Hari beransur sore, lareh itu terkejut dan dia ingat kebenaran lalu dia hanya mencuci muko dan dia tidak jadi mandi.'

Kalimat pada contoh data (17) merupakan kalimat majemuk campuran yang terdiri atas lima klausa yaitu: klausa (1) hari baransua rambang sanjo 'hari beransur sore', klausa (2) sanan takajuik lareh nantun 'di sana terkejut laras itu', klausa (3) takana bana dek inyo 'teringat kebenaran olehnya', klausa (4) lalu dibasuah sajo malah muko 'lalu dicuci saja muka', dan klausa (5) indak jadi baliau mandi 'tidak jadi beliau mandi'. Antarklausa ditandai dengan tanda koma dan konjungtor lalu 'lalu'. Tanda koma digunakan untuk menghubungkan klausa (1 dengan klausa (2), klausa (2) dengan klausa (3), dan klausa (4) dengan klausa (5). Sebaliknya, konjungtor lalu 'lalu' digunakan untuk menghubungkan klausa (3) dengan klausa (4).

Struktur setiap klausa pada kalimat majemuk tersebut adalah seperti berikut, klausa (1) berstruktur S-P-Pel, klausa (2) berstruktur Ket-P-S, 
klausa (3) berstruktur P-Pel-Ket, klausa (4) berstruktur Konj-P-Pel, dan klausa (5) berstruktur P-S-P. Dengan demikian, struktur kalimat majemuk campuran tersebut adalah S-P-Pel,Ket-P-S,P-Pel-Ket,Konj-P-Pel,P-S-P. Selanjutnya, klausa (1), (2), dan (5) termasuk klausa lengkap, sedangkan klausa (3) dan (4) termasuk klausa tak lengkap. Selain itu, klausa (2) dan klausa (5) termasuk klausa inversi karena fungsi sintaksis P mendahului fungsi sintaksis $S$ pada klausa tersebut.

(18) Salasai surek dibaco, sanang raso kiro-kiro, tabayang sakali roman Siti $\begin{array}{lllllll}\text { Konj } & \text { S } & \text { P } & \text { P } & \text { S } & \text { P } & \text { S }\end{array}$ Rawani, $\frac{\text { bajalan }}{\mathrm{P}} \frac{\text { inyo }}{\mathrm{S}} \frac{\text { sakali, }}{\mathrm{Pel}} \frac{\text { maadok }}{\mathrm{P}} \frac{\mathrm{ka} \mathrm{rumah} \mathrm{Siti} \mathrm{Rawiyah.}}{\mathrm{Ket}}$

' Setelah surat dibaca, hati senang lalu terbayang wajah Siti Rawani dan dia berjalan menuju ke rumah Siti Rawiyah.'

Kalimat pada contoh (18) di atas adalah kalimat majemuk campuran yang terdiri atas lima klausa. Klausa-klausa itu adalah seperti berikut ini: klausa (1) salasai surek dibaco 'selesai surat dibaca', klausa (2) sanang raso kiro-kiro 'hati menjadi senang', klausa (3) tabayang sakali roman Siti Rawani 'terbayang wajah Siti Rawani', klausa (4) bajalan inyo sakali 'dia langsung berjalan', dan klausa (5) maadok ka rumah Siti Rawiyah 'menghadap ke rumah Siti Rawiyah'. Selanjutnya, klausa (1) dihubungkan dengan klausa (2) menggunakan konjungtor salasai 'selesai', sedangkan klausa (2) dengan kluasa (3), klausa (4), dan dengan klausa (5) tidak menggunakan konjungtor, tetapi menggunakan tanda koma.

Struktur tiap-tiap klausa pada kalimat majemuk campuran itu adalah sebagai berikut: klausa (1) mempunyai struktur Konj-S-P, klausa (2) mempunyai struktur P-S, klausa (3) mempunyai struktur P-S, klausa (4) mempunyai struktur P-S-Pel, dan klausa (5) mempunyai struktur P-Ket. Dengan demikian, struktur kalimat majemuk campuran itu adalah Konj-SP,P-S,P-S,P-S-Pel,P-Ket.

(19) Alah sudah batimbang tando, baliaupun sugiro turun ka laman, diiriang$\begin{array}{lllllll}\text { Konj } & P & \text { Pel } & \text { S } & \text { P } & \text { Ket } & \text { P }\end{array}$ kan dek Angku Kapalo.

Ket

' Setelah selesai bertukar tanda, beliau pun segera turun ke halaman dan diiringkan oleh Angku Kapalo.' 
Kalimat (19) di atas termasuk kalimat majemuk campuran yang terdiri atas tiga klausa yaitu: klausa (1) alah sudah batimbang tando 'setelah selesai bertukar tanda', klausa (2) baliaupun sugiro turun ka laman 'beliau pun segera turun ke halaman', dan klausa (3) diiriangkan dek Angku Kapalo 'diiringkan oleh Angku Kapalo'. Selanjutnya, klausa (1) dihubungkan dengan klausa (2) menggunakan konjungtor alah sudah 'setelah selesai'. Sebaliknya, antarklausa (2) dengan (3) tidak menggunakan konjungtor, tetapi menggunakan tanda koma.

Struktur kalimat majemuk campuran ini adalah Konj-P-Pel,S-P-Ket,PKet. Struktur ini merupakan gabungan dari struktur klausa-klausa yang membentuk kalimat majemuk campuran itu. Selanjutnya, struktur setiap klausa adalah seperti berikut ini, struktur klausa (1) adalah Konj-P-Pel, klausa (2) adalah S-P-Ket, dan klausa (3) p-Ket.

(20) Birawari rang jago gadang, mandanga kato nan bak kian, lalu diambiak $\begin{array}{llll}\text { Ket } & \mathrm{S} & \mathrm{P} & \mathrm{O}\end{array}$ sabik jo rajuik, diirik kudo nan putiah ka batang aia. Pel P Pel Ket

' Pada suatu hari penjaga mendengar kata seperti itu lalu diambilnya sabit dan rajut kemudian ditariknya kuda putih ke sungai.'

Pada contoh (20) terdapat empat klausa yang membentuk kalimat majemuk campuran. Klausa-klausa tersebut adalah seperti berikut ini, klausa (1) birawari rang jago gadang 'pada suatu hari penjaga', klausa (2) mandanga kato nan bak kian 'mendengar kata seperti itu', klausa (3) lalu diambiak sabik jo rajuik 'lalu diambil sabit dan rajut', dan klausa (4) diirik kudo nan putiah ka batang aia 'ditarik kuda putih ke sungai. Pada kalimat majemuk itu digunakan konjungtor lalu 'lalu' untuk menghubungkan klausa (2) dengan klausa (3). Sebaliknya, untuk menghubungkan klausa (1) dengan klausa (2) dan untuk menghubungkan klausa (3) dengan klausa (4) menggunakan tanda koma.

Struktur tiap-tiap klausa tersebut adalah sebagai berikut ini, klausa (1) berstruktur Ket-S, klausa (2) berstruktur P-O, klausa (3) berstruktur P-Pel, dan klausa (4) berstruktur P-Pel-Ket. Dengan demikian, struktur kalimat majemuk campuran ini adalah Ket-P,P-O,P-Pel,P-Pel-Ket.

(21) Sasudah mamakai Siti Jamilah, dibaok tagak ka camin gadang, bakato $\begin{array}{llllllll}\text { Konj } & P & S & P & P & \text { Ket } & P\end{array}$ 
maso itu.

Ket

' Setelah Siti Jamilah memakai pakaian lalu berdiri di depan cermin dan berkata ketika itu.'

Contoh data (21) merupakan kalimat majemuk campuran. Kalimat majemuk ini menggunakan konjungtor sasudah 'sesudah' untuk menghubungkan klausa (1) dengan klausa (2), tetapi tidak menggunakan konjungtor untuk menghubungkan klausa (2) dengan klausa (3) melainkan menggunakan tanda koma. Selanjutnya, kalimat majemuk ini terdiri atas tiga klausa yaitu: klausa (1) sasudah mamakai Siti Jamilah'sesudah Siti Jamilah memakai' yang berstruktur Konj-P-S, klausa (2) dibaok tagak ka camin gadang 'dibawa tegak ke cermin besar' yang berstruktur P-P-Ket, dan klausa (3) bakato masa itu 'berkata ketika itu' yang berstruktur P-Ket. Jadi, struktur kalimat majemuk ini adalah Konj-P-S, P-P-Ket,P-Ket.

(22) Ditutuik pintu kasadonyo, disingkokkan cando kulambu laloklah inyo

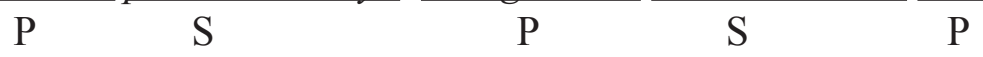
katigonyo, di kida Siti Darama, nan disuok si Asamsuddin. S Ket S Ket S

' Semua pintu ditutup lalu kelambu dibuka kemudian mereka tidur,di kiri Siti Darama, yang di kanan Si Asamsuddin.'

Kalimat pada contoh (22) termasuk pada jenis kalimat majemuk setara karena semua klausa pada kalimat itu mempunyai kedudukan yang sama. Pada kalimat majemuk setara ini tidak menggunakan konjungtor, tetapi menggunakan tanda koma saja untuk menghubungkan antarklausa. Sungguhpun begitu, kalimat ini berterima dalam bahasa Minangkabau. Selanjutnya, kalimat majemuk ini terdiri atas lima klausa yaitu: klausa (1) ditutuik pintu kasadonyo 'ditutup pintu semuanya', klausa (2) disingkokkan candokulambu'dibukakan kelambu', klausa (3) laloklah inyo katigonyo'tidurlah mereka ketiganya', klausa (4) di kida Siti Darama 'di kiri Siti Darama', dan klausa (5) nan di suok Si Asamsuddin 'yang di kanan Si Asamsuddin'.

Selain itu, tiap-tiap klausa dalam kalimat majemuk setara tersebut mempunyai struktur masing-masing. Struktur-struktur tersebut adalah sebagai berikut, struktur klausa (1) adalah P-S, klausa (2) P-S, klausa (3) P-S, klausa (4) Ket-S, dan klausa (5) Ket-S. Jadi, struktur kalimat majemuk setara tersebut adalah P-S,P-S,P-S,Ket-S,Ket-S. 
(23) Aluran Sutan Nasarudin, alah salasai surek dikarang, alah cukuik $\begin{array}{lllll}\text { S } & \text { Konj } & \text { S } & \text { P } & \text { P }\end{array}$ pantun jo ibarat, lalu dibungkuih hanyo lai, sanan diimbau Bujang $\begin{array}{lllll}\mathrm{S} & \text { Konj } & \mathrm{P} & \text { Ket Ket } \mathrm{P}\end{array}$

Salamat. $\mathrm{S}$

' Sutan Nasaruddin sudah selesai menulis surat dengan pantun dan ungkapan lalu surat itu dibungkusnya kemudian dipanggil si Bujang Selamat.'

Contoh kalimat pada data (23) merupakan kalimat majemuk campuran yang terdiri atas lima klausa yaitu: klausa (1) aluran Sutan Nasaruddin 'Sutan Nasaruddin', klausa (2) alah salasai surek dikarang 'sudah selesai menulis surat', klausa (3) alah cukuik pantun jo ibarat 'sudah cukup pantun dan ungkapan', klausa (4) lalu dibungkuih hanyo lai 'lalu dibungkus', dan klausa (5) sanan diimbau Bujang Salamat 'dipanggil Bujang Salamat'.Antarklausa ada yang menggunakan konjuntor yaitu konjungtor alah salasai 'setelah salasai' dan lalu 'lalu' untuk menghubungkan klausa (1) dengan klausa (2) dan menghubungkan klausa (3) dengan klausa (4). Sebaliknya, klausa (2) dengan klausa (3) dan klausa (4) dengan klausa (5) tidak menggunakan konjungtor untuk menghubungkan antarklausa itu, tetapi menggunakan tanda koma.

Struktur kalimat majemuk campuran tersebut adalah S,Konj-S-P,PS,Konj-P-Ket,Ket-P-S. Selain itu, struktur tiap-tiap klausa adalah seperti di bawah ini, klausa (1) berstruktur S, klausa (2) berstruktur Konj-S-P, klausa (3) berstruktur P-S, klausa (4) berstruktur Konj-P-Ket, dan klausa (5) berstruktur Ket-P.

(24) Alah tibo di tangah laman, mamandang inyo ka labuah gadang, sanan $\begin{array}{llllll}\mathrm{P} & \text { Ket } & \mathrm{P} & \mathrm{S} & \text { Ket } & \text { Ket }\end{array}$ disongsong dek Sutan Nasaruddin, bajawek salam bapegang jari, nan $\mathrm{P} \quad$ Ket $\mathrm{P} \quad \mathrm{P}$

tidak dilapehkan sampai ka ateh oto, maliek kapado arloji tangan, $\mathrm{P} \quad$ Ket $\mathrm{P}$ Ket

hari basarang laruik juo, kinilah pukua satu liwat saparampek, oto S P Pel Ket $\quad$ Ket barangkek hanyo lai. $\mathrm{P}$ 
' Dia sudah sampai di halaman dan memandang ke jalan besar dan disongsong oleh Sutan Nasaruddin kemudian mereka berpegangan tangan yang tidak dilepaskan sampai ke mobil lalu melihat jam tangan yang sudah menunjukkan pukul 01: 15 lalu mobil berangkat.'

Kalimat pada contoh data (24) merupakan kalimat majemuk campuran. Kalimat majemuk campuran ini terdiri atas sembilan klausa yaitu: kluasa (1) alah tibo di tangah laman 'setelah tiba di tengah halaman', klausa (2) mamandang inyo ka labuah gadang 'dia memandang ke jalan besar', klausa (3) sanan disongsong dek Sutan Nasarudin 'di sana disongsong oleh Sutan Nasarudin', klausa (4) bajawek salam bapegang jari 'berjawab salam berpegangan tangan', klausa (5) nan tidak dilapehkan sampai ka ateh oto 'yang tidak dilepaskan sampai ke atas mobil', klausa (6) maliek kapado arloji tangan 'melihat jam tangan', klausa (7) hari basarang laruik juo 'hari sudah larut juga', klausa (8) kinilah pukua satu liwat saparampek'sekarang pukul 01.00$15^{\prime}$, dan klausa (9) oto barangkek hanyo lai 'lalu mobil berangkat'. Antarklausa pada kalimat majemuk campuran itu menggunakan konjungtor alah 'setelah' untuk menghubungkan klausa (1) dengan klausa (2), sedangkan antarklausa yang lainnya tidak menggunakan konjungtor.

Setiap klausa pada kalimat majemuk campuran ini mempunyai struktur masing-masing. Struktur setiap klausanya adalah sebagai berikut: klausa (1) berstruktur P-Ket, klausa (2) berstruktur P-S-Ket, klausa (3) berstruktur Ket-P-Ket, klausa (4) berstruktur P-P, klausa (5) berstruktur P-Ket, klausa (6) berstruktur P-Ket, klausa (7) berstruktur S-P-Pel, klausa (8) berstruktur Ket-Ket, dan klausa (9) berstruktur S-P. Dengan demikian, struktur kalimat majemuk campuran ini adalah P-Ket,P-S-Ket,Ket-P-Ket,PP,P-Ket,P-Ket,S-P-Pel,Ket-Ket,S-P.

(25) Pado kutiko itu juo, datanglah Datuak Mangkuto Rajo, mamak kanduang Ket $\mathrm{P}$

Si Siti Arabainah, alah duduak di ateh rumah, lalu batanyo maso it.

$$
\mathrm{P} \text { Ket } \mathrm{P} \text { Ket }
$$

' Pada waktu itu juga, datanglah Datuak Mangkuto Rajo, saudara laki-laki ibu Si Siti Arabainah dan sudah duduk di atas rumah lalu bertanya ketika itu.'

Data (25) merupakan contoh kalimat majemuk bahasa Minangkabau yang digunakan dalam kaba. Kalimat majemuk ini termasuk kalimat majemuk campuran yang terdiri atas tiga klausa yaitu: klausa (1) pado kutiko 
itu juo datanglah DatuakMangkuto Rajo,mamak kanduang Si Siti Arabainah 'pada waktu itu datanglah Datuk Mangkuto Rajo', klausa (2) alah duduak di ateh rumah 'sudah duduk di atas rumah', dan klausa (3) lalu batanyo maso itu 'lalu bertanya masa itu. Selanjutnya, struktur tiap-tiap klausa dalam kalimat majemuk campuran itu adalah seperti berikut ini, klausa (1) mempunyai struktur Ket-P-S, klausa (2) mempunyai struktur P-Ket, dan klausa (3) mempunyai struktur P-Ket. Jadi, struktur kalimat majemuk campuran tersebut adalah Ket-P-S,P-Ket, P-Ket.

\section{PENUTUP}

Berdasarkan pembahasan yang telah dilakukan, dapat disimpulkan beberapa hal tentang penggunaan kalimat majemuk bahasa Minangkabau dalam kaba yang merupakan karya sastra tradisional masyarakat Minangkabau. Hal-hal yang dapat disimpulkan adalah seperti berikut ini.

Kalimat majemuk bahasa Minangkabau yang digunakan dalam kaba terdiri atas tiga jenis yaitu: kalimat majemuk setara, kalimat majemuk bertingkat, dan kalimat majemuk campuran.

Kalimat majemuk bahasa Minangkabau yang digunakan dalam kaba terdiri atas beberapa klausa antaralain: tiga klausa, empat klausa, lima klausa, enam klausa, tujuh klausa, dan sembilan klausa.

Kalimat majemuk bahasa Minangkabau yang digunakan dalam kaba menggunakan konjungtor antaralain: kok 'kalau', dek 'karena', jo 'dan/ dengan', lalu 'lalu', sarato 'dan', sasudah 'sesudah'.

Kalimat majemuk bahasa Minangkabau yang digunakan dalam kaba mempunyai struktur antaralain: P-S,P-P-K; Konj-P-Pel-Konj-Pel-Ket,S-SP,S-P,S-P; P-S,P-S,P-S,Ket-S,Ket-S; P-S,P-S,P-S,Ket-S,Ket-S; Ket-P,P-O,PPel,P-Pel-Ket; P-O,P-S,P-Ket,S-P; Ket-P-S,P-Ket, P-Ket; P-Ket,P-S-Ket,KetP-Ket,P-P,P-Ket,P-Ket,S-P-Pel,Ket-Ket,S-P.

\section{DAFTAR PUSTAKA}

Alieva, N.F. dkk. 1991. Bahasa Indonesia Deskripsi dan Teori. Yogyakarta ; Kanisius.

Alwi, Hasan. dkk. 2000 Tata Bahasa Baku Bahasa Indonesia Edisi Ketiga, Jakarta : Balai Pustaka.

Arifin, Zaenal, dan Junaiyah. $\quad$ 2008. Sintaksis. Jakarta : PT. Grasindo Junus, Umar. 1984 Kota dan Sistem Sosial Minangkabau. Jakarta : PN Balai 
Efri Yades

\section{Pustaka.}

Navis, A. A. 1986. Alam Terkembang Jadi Guru. Cetakan Kedua. Jakarta : PT. Temprint.

Parera, Jos Daniel. 1994. Sintaksis, Jakarta : Gramedia Oustaka Utama Putrayasa, Ida Bagus. 2007. Analisis Kalimat. Bandung: Refika Aditama Ramlan. M. 1995. Sintaksis, Cetakan Kettujuh. Yogyakarta : CV. Karyono Sudaryanto. 1987. Ilmu Linguistik Bagian Pertama. Yogyakarta : Gajah Mada University. 